\title{
PEMBUATAN MEDIA PEMBELAJARAN BERBASIS MULTIMEDIA BAGI GURU SEKOLAH DASAR (SD) KECAMATAN RUMBAI KOTA PEKANBARU PROVINSI RIAU
}

\author{
Refika Andriani ${ }^{1}$, Destina Kasriyati ${ }^{2}$ \\ ${ }^{1}$ Universitas Lancang Kuning. Email: andriarefi@gmail.com \\ 2Universitas Lancang Kuning. Email: destinakasriyati@gmail.com
}

\begin{abstract}
This program aims at improving Elementary teachers' skill in Rumbai Pekanbaru in developing multimedia as an interesting and motivated teaching media in the classroom in order to create a pleasant learning atmosphere to improve the students' learning outcome. This program has been handling from March to October 2018 with some phases. This program has some phase there are observation, socialization, training, monitoring, and evaluation. The outcomes targeted were teacher's skill improvement, scientific paper, learning media, and mass media publication. Training phase was conducted on 24 to 26 of May, 2018 in Language Center of University of Lancang Kuning. There were 9 participants who followed this training and they have been developing draft of multimedia as a learning media and it will be completed in few months later with help and guidance from the team of this program through monitoring phase. In the end of the training, participants said that this program was really useful and motivate them to improve their skill in developing and using multimedia as a learning media in the classroom.
\end{abstract}

Keywords: Multimedia, learning media, Elementary School teachers

\begin{abstract}
ABSTRAK
Program ini bertujuan untuk meningkatkan keterampilan guru - guru Sekolah Dasar di Kecamatan Rumbai Kota Pekanbaru Provinsi Riau dalam mengembangkan sebuah media pembelajaran berbasis multimedia yang menarik dan memotivasi untuk digunakan dalam proses pembelajaran di kelas. Kegiatan ini dilaksanakan dalam delapan bulan terhitung mulai bulan Maret hingga bulan Oktober tahun 2018 dengan beberapa tahapan. Program ini memiliki beberapa tahapan yaitu Observasi, Sosialisasi, Pelatihan, Monitoring, dan Evaluasi. Adapun luaran yang menjadi target capaian dari kegiatan ini adalah adanya peningkatan keterampilan guru, karya ilmiah yang dipublikasikan, media pembelajaran, dan publikasi pada media massa. Tahapan pelatihan dan pendampingan pembuatan media telah dilaksanakan pada 24 - 26 Mei 2018 bertempat di Balai Bahasa Universitas Lancang Kuning. Terdapat 9 peserta yang mengikuti pelatihan ini dan mereka telah mengembangkan draf media pembelajaran berbasis multimedia dan media tersebut akan selesai dalam beberapa bulan kemudian dengan bantuan dan bimbingan dari tim program ini melalui tahapan monitoring. Di Akhir kegiatan para pelatih dan peserta mengatakan bahwa program ini sangat berguna dan mampu memotivasi mereka untuk meningkatkan kemampuan merekan dalam mengembangkan dan menggunakan multimedia sebagai media pembelajaran di kelas
\end{abstract}

Kata Kunci: Media Pembelajaran, Mulitimedia, Guru Sekolah Dasar

\section{PENDAHULUAN}

Minimnya keikutsertaan para guru pada program pelatihan untuk meningkatkan wawasan dan keterampilan terkait dengan proses pembelajaran tentunya akan berdampak pada rendahnya motivasi dan kreatifitas para guru tersebut dalam mengembangkan berbagai metode, strategi, dan media pembelajaran yang dapat mereka terapkan dalam kegiatan pembelajaran di kelas. Sebagai hasil, minat belajar dan hasil belajar siswapun menjadi rendah dan pembelajaran menjadi kurang bermakna. Jika sudah seperti itu, maka target capaian kurikulum menjadi sulit diraih. 
SD Negeri 128 Pekanbaru dan SD Negeri 174 Pekanbaru adalah dua Sekolah Dasar yang berada di kecamatan Rumbai Kota Pekanbaru. Dua sekolah ini berada di lingkungan yang terbilang jauh dari pusat kota. Oleh sebab itu, tim pengusul mencoba menggali informasi mengenai kebutuhan pengembangan kompetensi guru yang dapat menunjang tugas mereka dalam proses mengajar. Berdasarkan hasil survey awal yang telah dilakukan terhadap sejumlah guru dan kepala Sekolah Dasar (SD) di kecamatan Rumbai tersebut, maka dapat diperoleh informasi bahwa dalam praktik pembelajaran sehari-hari para guru seringkali menerapkan metode dan menggunakan media pembelajaran yang konvensional dan seadanya. Hal ini disebabkan oleh beberapa faktor yaitu guru merasa tidak memiliki wawasan yang cukup terkait dengan penerapan metode mengajar yang lebih baik dan terbaru, serta guru tidak memiliki keterampilan dasar yang cukup dalam mengembangkan media pembelajaran yang modern. Sehingga menyebabkan guru tidak memiliki motivasi dan kreatifitas untuk mengembangkan metode mengajar yang digunakannya dalam proses pembelajaran. Keadaan ini sangat disayangkan sekali, mengingat guru di sekolah-sekolah tersebut sudah memiliki fasilitas yang cukup memadai yang dapat digunakan dalam proses pembelajaran seperti laptop dan LCD proyektor.

Berdasarkan pertimbangan tersebut, tim dosen (pengusul program PKM) menawarkan solusi terhadap permasalahan yang dihadapi oleh para guru di Sekolah Dasar Kecamatan Rumbai Kota Pekanbaru tersebut melalui kegiatan pendampingan pembuatan media pembelajaran berbasis multimedia. Kegiatan ini dipandang sangat perlu karena diharapkan mampu memberikan kontribusi bagi guru-guru tersebut khususnya dalam memperoleh keterampilan yang baik dalam membuat media pembelajaran berbasis multimedia.

Menurut Vaughan (2004, p1), multimedia adalah beberapa kombinasi dari teks, gambar, suara, animasi dan video dikirim ke anda melalui komputer atau alat elektronik lainnya atau dengan manipulasi digital. Sehingga, Pemilihan media pembelajaran berbasis multimedia ini mengingat bahwa multimedia merupakan bagian dari Informasi dan Teknologi (IT) yang mengandung unsur grafis, teks, suara, video, dan animasi. Penggabungan ini merupakan suatu kesatuan yang secara bersama-sama menampilkan informasi, pesan, atau isi pelajaran. Multimedia bertujuan untuk menyajikan informasi dalam bentuk yang menyenangkan, menarik, mudah dimengerti, dan jelas. Dengan demikian, dapat disimpulkan bahwa dengan menggunakan media ini guru mampu meningkatkan kualitas kegiatan pembelajaran yang mereka laksanakan di dalam kelas.

\section{METODE PELAKSANAAN}

Berikut dijelaskan teknologi yang ditawarkan dalam upaya produksi media pembelajaran berbasis multimedia dan teknis penggunaannya. Adapun proses desain/perancangan media pembelajaran berbasis multimedia dapat digambarkan sebagai berikut. 


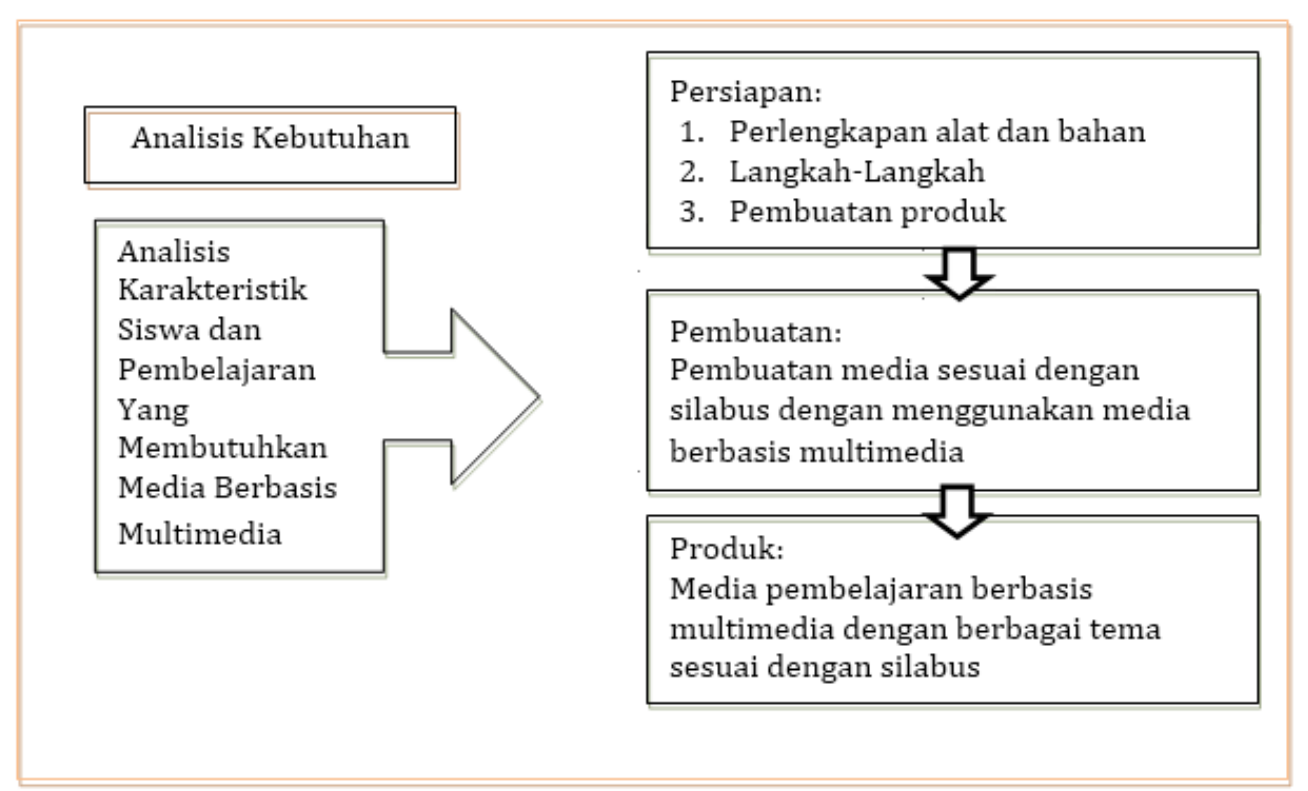

Diagram 1. Proses Pembuatan Media Pembelajaran Berbasis Multimedia

Adapun mekanisme pelaksanaan Program Kemitraan Masyarakat ini memiliki beberapa langkah yang terdiri dari 4 tahapan kegiatan; perencanaan, pelaksanaan, monitoring kegiatan, dan evaluasi. Di mana mekanisme kegiatan Program Kemitraan Masyarakat ini akan dijelaskan secara terperinci dalam diagram dibawah ini:

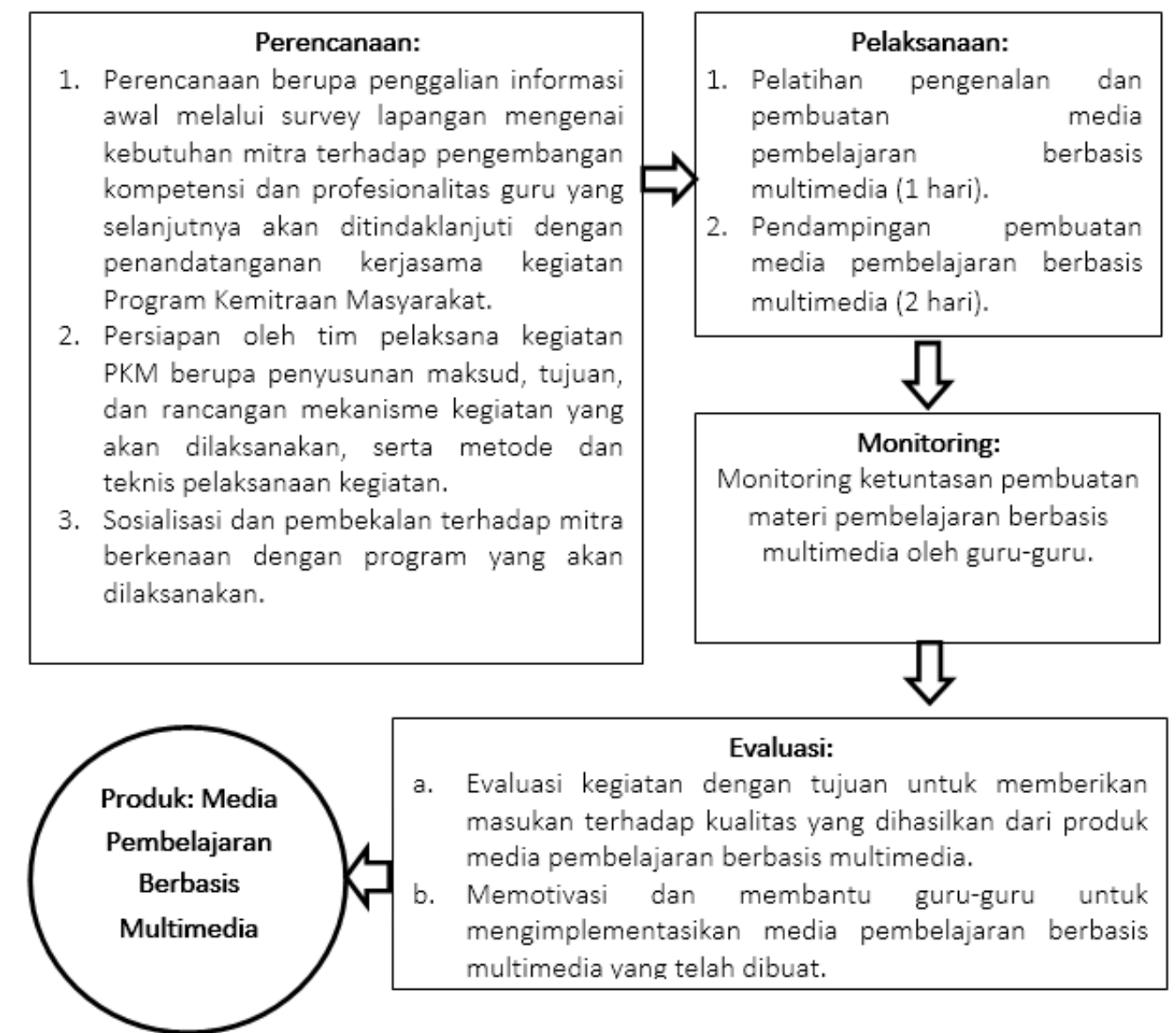

Diagram 2. Mekanisme Kegiatan PKM Pembuatan Media Pembelajaran Berbasis Multimedia 


\section{HASIL DAN PEMBAHASAN Hasil}

Tahapan pelatihan dan pendampingan kegiatan Program Kemitraan Masyarakat ini telah dilaksanakan selama 3 hari pada tanggal 24-26 Mei 2018, pada pukul 09.00 15.00 WIB di Balai Bahasa Universitas Lancang Kuning. Pemilihan gedung Balai Bahasa Universitas Lancang Kuning sebagai tempat dilaksanakannya kegiatan didasarkan pada keputusan bersama antara pihak Sekolah Mitra dan tim pelaksana. Kegiatan ini berjalan lancar sesuai dengan yang diharapkan dengan diikuti oleh 9 peserta yang berasal dari Sekolah Dasar (SD) sekecamatan Rumbai Kota Pekanbaru.

Pada hari pertama, tim pelaksana kegiatan memberikan gambaran umum mengenai kegiatan Program Kemitraan Masyarakat (PKM) yang akan dilaksanakan. Selanjutnya tim pelaksana memberikan pengetahuan umum terkait dengan pengaplikasian teknologi modern dalam dunia pendidikan, keterampilan dalam pengelolah kelas, dan metode-metode serta berbagai strategi yang dapat digunakan oleh guru untuk menciptakan suasana belajar yang mampu memotivasi peserta didik dalam belajar sehingga tercapai tujuan belajar yang diinginkan dan telah ditargetkan. Kegiatan hari pertama berlangsung kurang kondusif dikarenakan sebagaian besar materi yang disampaikan merupakan pengetahuan umum berupa teori. Di akhir pelaksanaan kegiatan PKM hari pertama, tim pelaksana mengingatkan para peserta guru untuk mempersiapkan berbagai materi ajar yang dibutuhkan untuk membuat media pembelajaran di hari kedua.

Pada hari kedua, kegiatan diawali dengan pengetahuan dasar mengenai media pembelajaran berbasis multimedia. Selain itu, tim pelaksana memberikan berbagai contoh media pembelajaran berbasis multimedia yang dapat digunakan dalam proses pembelajaran di dalam kelas. Hal ini sangat memotivasi para peserta pelatihan untuk segera memulai kegiatan pembuatan media pembelajaran berbasis multimedia. Setelah memperoleh pengetahuan yang cukup terkait dengan beberapa media pembelajaran berbasis multimedia, maka para peserta memulai kegiatan pembuatan media pembelajaran dengan menggunakan materi ajar yang sudah disiapkan sebelumnya. Pada proses pembuatan media pembelajaran ini, tim pelaksana memfokuskan pada pengembangan media pembelajaran berbasis multimedia dengan memanfaatkan fitur slide master yang tersedia di Microsoft power point. Pemilihan fitur slide master didasarkan pada situasi dan kondisi para peserta pelatihan yang memiliki pengetahuan sangat minim terkait dengan penggunaan laptop.

Di hari ketiga pelaksanaan kegiatan PKM, peserta pelatihan masih sangat bersemangat dalam menyelesaikan media pembelajarannya. Hal ini tampak dari para peserta pelatihan dan pengembangan media pembelajaran berbasis multimedia yang mengikuti kegiatan ini dengan sangat aktif dan menunjukkan interaksi yang positif. Sehingga para peserta dapat menghasilkan draft media pembelajaran berbasis multimedia yang baik. Draft ini yang menjadi bekal bagi para guru untuk diselesaikan di rumah ataupun di Sekolah sehingga menjadi sebuah media pembelajaran yang sempurna. Berikut adalah contoh tampilan draft media pembelajaran berbasis multimedia yang dibuat oleh salah seorang peserta pelatihan. 


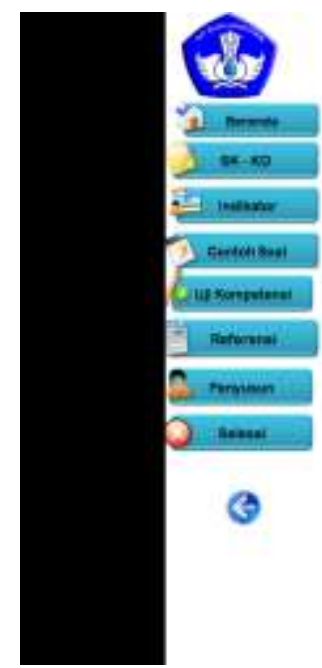

\section{Maryeti, s.pd}

Salam smart ananda, are

you happy?

Gambar 1. Tampilan Draft Media Pembelajaran Berbasis Multimedia Miliki Peserta

Untuk menyelesaikan draft media pembelajaran tersebut menjadi sebuah media yang sempurna dan layak dipakai di dalam kelas, maka guru melanjutkan kegiatan pembuatan media pembelajaran di luar pelatihan yang sudah terjadwal. Kegiatan monitoring dilaksanakan oleh tim pelaksana kegiatan dengan tujuan untuk memberikan bantuan dan memantau kesiapan guru dalam menyelesaikan draft media pembelajaran yang sudah dibuat pada saat pelatihan sebelumnya. Dengan adanya monitoring diharapkan setiap guru tidak menemui hambatan yang berarti dan tetap memiliki motivasi yang tinggi dalam menyelesaikan draft media pembelajarannya.

Selanjutnya, evaluasi akan dilaksanakan oleh tim pelaksana untuk memberikan masukan terhadap kualitas yang dihasilkan dari produk media pembelajaran berbasis multimedia yang dibuat oleh guru. Dengan demikian, produk media pembelajaran yang dihasilkan oleh para guru memiliki kualitas yang baik dan layak dipakai dalam proses pembelajaran sehingga dapat dimanfaatkan seterusnya dalam proses pembelajaran di kelas. Selain itu, tim pelaksana akan terus berusaha memberikan motivasi bagi guru untuk terus membuat dan menghasilkan media pembelajaran berbasis multimedia dengan materi-materi yang bervariasi.

\section{Pembahasan}

Demi mengukur sejauh mana manfaat dan keberhasilan kegiatan PKM ini, maka sebelum dan setelah pelaksanaan kegiatan pembuatan media pembelajaran berbasis multimedia selama 3 hari, para peserta pelatihan memberikan tanggapannya melalui angket yang diberikan oleh tim pelaksana. Angket yang diberikan oleh tim pelaksana terdiri dari dua jenis, pre-test dan post-test.

Hasil dari pre-test dapat disimpulkan bahwa para peserta sudah mengajar lebih dari 10 tahun yaitu sebanyak 5 orang. Hal ini menunjukkan bahwa para peserta sudah sangat banyak memiliki pengalaman mengajar baik itu menggunakan media ajar atau media pembelajaran yang bervairiasi. Kemudian, ditemukan sebanyak 7 peserta yang telah menggunakan media pembelajaran. Hal ini menunjukkan bahwa para peserta tidak canggung lagi menggunakan media pembelajaran di sekolah ketika mengajar. Sayangnya, frekuensi guru-guru dalam menggunakan media pembelajaran sangat jarang atau hampir tidak pernah. Selain itu, media pembelajaran yang digunakan guru adalah media ajar yang 
sederhana seperti gambar atau alat peraga yang telah tersedia. Hal ini terjadi akibat kurangnya guru-guru memperoleh pelatihan tentang multimedia sebagai media pembelajaran. Selanjutnya, sebagian besar peserta memperoleh hambatan dalam menggunakan media pembelajaran yaitu tidak tersedianya media pembelajaran yang bervariasi di sekolah.

Berdasarkan data yang diperoleh melalui interview dengan sejumlah guru dan kepala sekolah, dapat disimpulkan bahwa peserta memiliki motivasi yang begitu rendah dalam menggunakan multimedia sebagai media pembelajaran. Hal ini disebabkan oleh hampir tidak pernahnya para guru mendapatkan kesempatan untuk mengikuti pelatihan pembuatan media khususnya yang berbasis multimedia. Keadaan tersebut membuat guru tidak terampil dalam membuat dan megoperasikan media pembelajaran berbasis multimedia. Selain itu, fasilitas atau media pembelajaran yang tersedia di sekolah juga terbilang kurang memadai. Sebagai akibatnya, guru-guru hampir tidak pernah menggunakan media pembelajaran dalam proses pembelajaran. Kesimpulannya, diketahui bahwa para guru di Sekolah Dasar mitra sangat membutuhkan pelatihan berupa pengembangan media pembelajaran berbasis multimedia untuk menunjang proses pembelajaran yang mereka laksanakan di kelas.

Setelah kegiatan PKM berlangsung, maka tim pelaksana kembali memberikan angket berupa post-test. Berdasarkan hasil angket yang diberikan kepada para guru, dapat diketahui bahwa seluruh (100\%) guru masih membutuhkan pelatihan dan pengembangan media berbasis multimedia untuk pembelajaran tersebut, kemudian seluruh guru menyatakan bahwa setelah mengikuti pelatihan ini mereka sangat termotivasi untuk menggunakan dan mengembangkan media berbasis multimedia untuk pembelajaran. Untuk pernyataan berikutnya, 8 (88.8\%) guru menyatakan memahami tentang dasar-dasar media pembelajaran berbasis multimedia, sementara $1(16.7 \%)$ guru menyatakan masih belum mengetahui dasar-dasar media pembelajaran berbasis multimedia.

Kemudian, setelah mengikuti pelatihan ini seluruh (100\%) guru menyatakan akan menggunakan media berbasis multimedia untuk pembelajaran dalam proses belajar mengajar. Berikutnya, seluruh peserta (100\%) menyatakan bahwa media dan fasilitas pelatihan mendukung guru untuk dapat menggunakan dan mengembangkan media berbasis multimedia untuk pembelajaran. Pada pernyataan materi yang disampaikan pada pelatihan, seluruh $(100 \%)$ peserta memberikan pernyataan bahwa penyampaian materi tentang penggunaan dan pengembangan media berbasis multimedia pembelajaran yang didapatkan selama pelatihan sangat baik. Untuk pernyataan terakhir, seluruh (100\%) guru menyatakan ingin kembali mengikuti pelatihan yang sama.

Berdasarkan hasil angket tersebut, maka dapat disimpulkan bahwa pelatihan dan pengembangaan media berbasis multimedia untuk pembelajaran bagi guru Sekolah Dasar sekecamatan Rumbai ini sangat bermanfaat dan memotivasi para guru untuk memanfaatkan teknologi maju dalam proses mengajar demi mencapai tujuan pembelajaran. Selain itu, materi dan kecakapan tim pelaksana dalam menyampaikan materi pelatihan pembuatan media pembelajaran berbasis multimedia sangat mendukung para peserta untuk dapat mengembangkan keterampilan dalam 
mengembangkan media pembelajaran khususnya yang berbasis multimedia. Ke depannya, peserta pelatihan berharap agar kembali memperoleh kesempatan untuk mengikuti pelatihan yang sama.

\section{SIMPULAN}

Dari Kegiatan Program Kemitraan Masyarakat (PKM) yang telah dilakukan, dapat disimpulkan bahwa pengetahuan guru mengenai pentingnya penggunaan media pembelajaran berbasis multimedia dalam proses belajar mengajar meningkat setelah mengikuti pelatihan dan pendampingan. Selanjutnya, guru menjadi terampil dalam menggunakan dan mengembangkan multimedia sebagai media ajar dalam proses pembelajaran. Selain itu, kegiatan PKM yang dilaksanakan sangat bermanfaat dan memotivasi guru dalam meningkatkan kualitas pembelajaran dengan membuat dan menggunakan media pembelajaran berbasis multimedia dalam proses pembelajaran. Terakhir, guru-guru di sekolah mitra masih sangat membutuhkan kegiatan pelatihan dan pendampingan pembuatan media pembelajaran berbasis multimedia sehingga keterampilannya dapat terus berkembang.

\section{UCAPAN TERIMA KASIH}

Ucapan terima kasih juga kami sampaikan kepada Direktorat Riset dan Pengabdian Masyarakat Direktorat Jenderal Penguatan Riset dan Pengembangan Kementerian Riset, Teknologi, dan Pendidikan Tinggi, Lembaga Penelitian dan Pengabdian Kepada Masyarakat (LPPM) Universitas Lancang Kuning, Bapak/Ibu Reviewers, dan segenap pimpinan Universitas Lancang Kuning, dan Bapak/Ibu Guru di Sekolah Mitra yang telah bertungkus lumus dalam upaya mengembangkan media pembelajaran demi tercapainya cita-cita dan tujuan mencerdaskan kehidupan bangsa.

\section{DAFTAR RUJUKAN}

Arsyad, A. (2002). Media Pembelajaran. Jakarta: PT. Raja Grafindo Persada.

Gerlach \& Elly. (1980). Teaching and Media. Englewood Cliffs, New Jersey: Prentice Hall, Inc

Kurniawan, N. (2014). Kurikulum 2013 dan Pergeseran Peran Guru. Dikutip dari: http://bangka.tribunnews.com/2014/03/27/kurikulum-2013-dan-pergeseranperan-guru

Kurniawan, Andriani, R., and Kasriyati D. (2017). Pengembangan Media Animasi untuk Pembelajaran Bahasa Inggris Sekecamatan Rumbai Kota Pekanbaru. Dinamisia: Jurnal Pengabdian Kepada Masyarakat . (1)(1) 68-73.

Natasya, E.P.U. (2015.) Media Pembelajaran Berbasis Multimedia. Dikutip dari: http://ekanatasya999.blogspot.co.id/2015/06/media-pembelajaran-berbasismultimedia 7.html 
Andriani, R. (2016) "Improving Students' Vocabulary Mastery using Interactive Multimedia." ELT-Lectura 3.1

Rusman, dkk. (2011). Pembelajaran Berbasis Teknologi Informasi dan Komunikasi: Mengembangkan Profesionalisme Guru. Jakarta: PT. Rajagrafindo Persada.

Smaldino, Sharon E., et all. (2005). Instructional Technology and Media for Learning. New Jersey: Pearson Prentice Hall.

Vaughan, T. (2011). Multimedia: Making it Work (Eight Edition). London: Mc Graw Hill. 